\title{
Code of Ethics, Clawback Incentive Schemes, and Personal Value to Mitigate Earnings Management Intention
}

\author{
Erlinda Nur Khasanah ${ }^{1 *}$ and Mahfud Sholihin ${ }^{2}$
}

\begin{abstract}
:
Research aims: This study aimed to examine the role of a code of ethics and clawback incentive schemes to mitigate earnings management intention. This study also examined the effect of personal value on the relationship between the code of ethics and incentive schemes with earnings management intention.

Design/Methodology/Approach: The research method used in this study was an experimental approach with a factorial design of $2 \times 3$ between-subjects. The subjects were 83 students from the undergraduate and postgraduate of Accounting Program from a public university in Yogyakarta, Indonesia. To test the hypotheses, two-way ANOVA was used. mitigate earnings management intention. However, it should be completed by clear and strict sanctions for ethical violations. The results, however, showed that there were no significant different effects between clawback and bonus-only incentive schemes on earnings management intention. Additionally, this study provided empirical evidence that personal value did not moderate the relationship between the code of ethics and incentive schemes on earnings management intention.

Theoretical contribution/Originality: This study showed the causality relationship between the code of ethics and incentive scheme with earnings management intention through the use of experimental methods.

Practitioner/Policy implication: This study has important implications for company management in designing and implementing a code of ethics effectively, namely the company should provide sanctions for those who violate the code of ethics.

Research limitation/Implication: First, this study only examined earnings management in the form of real earnings management as the operating decisions. Second, most of the data collection was carried out after class, causing participants to lack concentration as they were tired of the lessons in class. Keywords: Earnings Management Intention; Code of Ethics; Clawback Incentive Schemes; Personal Value
\end{abstract}

Department of Accounting,
Universitas Gadjah Mada, Daerah Istimewa Yogyakarta, Indonesia.

*CORRESPONDENCE:

erlindanur.kha@gmail.com

THIS ARTICLE IS AVAILABLE IN:

http://journal.umy.ac.id/index.php/ai

DOI: 10.18196/jai.2102145

\section{CITATION:}

Khasanah, E. N. \& Sholihin, M. (2020). Code of Ethics, Clawback Incentive Schemes, and Personal Value to Mitigate Earnings Management Intention. Journal of Accounting and Investment, 21(2), 195-216.

\section{ARTICLE HISTORY}

Received:

17 Dec 2019

Reviewed:

3 Jan 2020

Revised:

19 Mar 2020

Accepted:

19 Apr 2020

\section{Introduction}

As a consequence of crimes in various corporations, such as Wr. Grace and Co. and McKesson HBOC Inc., the role of the accounting profession is spotlighted by the wider community. Wr. Grace and Co. is a specialized material and chemical industry located in Colombia, Maryland. This company was charged with hiding earnings in reserve accounts in good 


\author{
Khasanah \& Sholihin \\ Code of Ethics, Clawback Incentive Schemes, and Personal Value...
}

years and then tapping them in later years to mask actual slowing earnings (Makar, Alam, \& Pearson, 2000). Meanwhile, McKesson HBOC Inc. entangled in the opposite case. This company, engaged in the health industry, allegedly booked premature revenues by including in sales figure a substantial list of contracts that had not been finalized (Makar et al., 2000). These various examples of corporate crimes have resulted in the crisis of public confidence toward the accountant's professionalism this profession has not been able to provide accurate financial information for the community.

Along with the increased corporate crimes in the world, earnings management become a hot issue in accounting professionals and researchers (Hossain, Karim, \& Eddine, 2014). Earnings management is a questionable practice in financial reporting to obtain personal gains (Schipper, 1989). Earnings management has two opposite consequences, namely opportunistic and efficient. It is said as unethical behavior when carried out for opportunistic purposes.

Preventing unethical behavior in the workplace is a significant challenge for management (Kaptein, 2011). Creating an ethical climate in the work environment by providing a code of ethics can be taken as a management effort to prevent unethical behavior and to protect shareholders. A code of ethics may lead to appropriate business reporting and reliable financial information for shareholders (Kaptein, 2011). Management has a responsibility to shareholders to ensure that employees have worked ethically. The absence of the code of ethics may indicate that management did not consider ethics important (Adams, Tashchian, \& Shore, 2001).

Several previous studies showed that the code of ethics was a potential factor affecting ethical behavior (McCabe, Trevino, \& Butterfield, 1996; Rich, Smith, \& Mihale, 1990; Schwartz, 2002). Meanwhile, current studies have specifically linked the code of ethics to opportunistic behavior, such as an escalation of commitment to failing projects (Booth \& Schulz, 2004) and moral judgment of budgetary slack (Lucyanda \& Sholihin, 2016). Their studies provided evidence that the code of ethics could mitigate opportunistic behavior. However, studies examining whether the code of ethics was able to mitigate the other opportunistic behavior, namely earnings management intention, have not been widely explored. Therefore, this study aimed to fill this literature gap. Moreover, this study examined the issue using a different method from a similar study conducted by Chen, Gotti, Kang, and Wolfe (2016). Using an experimental method, this study was expected to contribute, especially validating that of Chen et al. (2016) study through the use of the different method. It was supported by Davidson and Stevens (2013), stating that current literature provides little empirical or theoretical support on the effectiveness of a code of ethics in an experimental settings. Therefore, the first objective of this study is to examine the role of the code of ethics in mitigating earnings management intention.

Several companies have implemented sanctions for the offenders of the code of ethics, but others have not. The implementation of sanctions showed that offending code of ethics is a serious problem (Brooks, 1989). Without sufficient procedures and policies to reduce unethical and illegal activities, the effectiveness of the code of ethics would be 


\author{
Khasanah \& Sholihin \\ Code of Ethics, Clawback Incentive Schemes, and Personal Value...
}

weak (Garegnani, Merlotti, \& Russo, 2015). Sanctions for the code of ethics violations by members of the organization are necessary to achieve its implementation effectiveness. Therefore, this study examined whether the implementation of the code of ethics, along with sanctions to the offenders, leads to different results compared to those without sanctions.

Incentives also had an important role in earnings management (Bergstresser \& Philippon, 2006). Previous studies have examined the effect of incentive and earnings management, but the results were still inconsistent. On the one hand, several studies, such as Reitenga, Buchheit, Yin, and Baker (2002); Burns and Kedia (2006); and Jouber and Fakhfakh (2014), provided empirical evidence on the relationship between incentive and earnings management. On the other hand, Beaudoin, Cianci, and Tsakumis (2015) and Laux and Laux (2009) did not find evidence that increased incentives can improve earnings management. Therefore, a research is required to provide empirical evidence related to determining the right incentive schemes to mitigate earnings management. This study examined whether the clawback incentive scheme could mitigate earnings management intention. Clawback is defined as recovering the CEO and CFO's incentive compensation if the restatement of accounting is attributed to intentional misconduct (Iskandar-Datta \& Jia, 2013).

Empirically, several studies provided evidence on the effectiveness of implementing clawback that it increased accounting quality and lower audit risk (Chan, Chen, Chen, \& $\mathrm{Yu}, 2012$ ); reduced financial misstatements and increased investors' confidence on earnings information (Chan, Chen, Chen, \& Yu, 2015); and could mitigate budgetary slack (Purnama \& Sholihin, 2017). The latest study on the clawback provision to curb earnings management was conducted by Sari and Sholihin (2019). Their study examined the interaction effect of clawback and religiosity on earnings management. The results provided empirical evidence that the interaction of religiosity and clawback had a significant effect. However, Sari and Sholihin (2019) only examined the interaction effect of religiosity and clawback on earnings management without examining the main effect of clawback. Therefore, this study empirically examined the extent to which the main effects of the clawback incentive scheme could mitigate earnings management intention.

Currently, limited studies were examining the interaction between organizational and personal factors on individual ethical decision making. The decision-making process is complex as it involves individual, organizational, and contextual issues (Jones, 1991). Moreover, the previous study of Ferrell and Gresham (1985) stated that individual factors (one of them is value) might interact with organizational factors in influencing ethical decision-making dilemmas. The interaction effect of personal values with organizational factors had been examined by Shafer, Morris, and Ketchand (2001). Their study examined these factors in the professional auditor's ethical decision process context. Hence, this study was intended to examine these factors concerning the other accounting context, namely, earnings management intention. Therefore, the third objective of this study was to examine the effect of personal value on the relationship between the code of ethics and incentive schemes on earnings management intention. 


\author{
Khasanah \& Sholihin \\ Code of Ethics, Clawback Incentive Schemes, and Personal Value...
}

This study used an experimental research method with a factorial design of $2 \times 3$ between-subjects. The subjects were 83 students from the undergraduate and postgraduate of Accounting Program from a public university in Yogyakarta, Indonesia. To test the hypotheses, this study used two-way ANOVA. This study found out that the code of ethics was able to mitigate earnings management intention. However, it should be completed by clear and strict sanctions. The results, however, showed that there were no significant different effects between clawback and bonus-only incentive schemes on earnings management intention. This study also provided empirical evidence that personal value did not moderate the relationship between the code of ethics and incentive schemes on earnings management intention.

This study has important implications for company management in designing and implementing a code of ethics effectively. This study suggests a company should design a code of ethics and to implement it effectively, it should be complemented with sanctions for those who violate the code of ethics. In terms of methodology, this study might show the causality relationship between the code of ethics and incentive scheme with earnings management intention through the use of the experimental method, which differs from the previous study by Chen et al. (2016), Chan et al. (2012); Chan et al. (2015), Iskandar-Datta and Jia (2013) and Pyzoha (2015) that used secondary data.

This paper consists of several sections. The next section describes the literature review and hypotheses development. The third section is the research method describing the experimental design, research subject and experiment task, definition of operational variable and measurement variable, and data analysis technique. The fourth section presents results and discussion, and the final section presents conclusions, limitations, and suggestions for future research.

\title{
Literature Review and Hypotheses Development
}

\section{Earnings Management}

Earnings management is a questionable practice in financial reporting to obtain personal gains (Schipper, 1989). Earnings management is generally conducted to attain a certain level of reported earnings (Gavious, Segev, \& Yosef, 2012). There are two perspectives of earnings management, opportunistic and efficient. Based on the opportunistic point of view, managers manipulate earnings to increase their interests, including increasing income and earnings and hiding "bad news", which can result in loss of bonuses or even being fired (Callen, Morel, \& Richardson, 2011). Opportunistic reporting behavior is designed to mislead some stakeholders to affect contractual outcomes with the intent of obtaining some private gains (Chen et al., 2016). Based on these motivations, it can be said that earnings management is the managers' opportunistic behavior due to an opportunity for managers/accountants to "manage" reported earnings (Bergstresser \& Philippon, 2006). Meanwhile, based on the efficient point of view, several studies argue that earnings management may be beneficial because it is potential to improve the value of earnings through informing private information to stockholders and the public 


\author{
Khasanah \& Sholihin \\ Code of Ethics, Clawback Incentive Schemes, and Personal Value...
}

(Jiraporn, Miller, Yoon, \& Kim, 2008; Rezaei \& Roshani, 2012). Under the condition where managers and shareholders are working in the same interest, managers will improve the firm's value and try to give their best prediction of future performance, therefore smoothing earnings presents a reasonable signal to outside investors (Putra, Pagalung, \& Habbe, 2018).

Earnings management practice is classified into two types, those involving changing accounting methods, and those involving operating decisions (Fischer \& Rosenzweig, 1995). Earnings management is related to changing accounting methods when management change policies of the company's accounting method to record transactions, such as changing the method of fixed asset depreciation, changing the method of a long-term contract, changing the method to record inventory, and changing the method to calculate production costs. The second type of earnings management is operating decisions, which involve delaying or accelerating recognition of transactions. The examples are offering special terms to customers at year-end to advance next year's sales (Fischer \& Rosenzweig, 1995), accelerating or delaying expenditures for promotions, and research and development cost up to the next accounting period.

\title{
Code of Ethics
}

A code of ethics is a document guiding the behavior of all the members of an organization (Rodriguez-Dominguez, Gallego-Alvarez, \& Garcia-Sanchez, 2009). Accountants are usually bound by the profession's code of ethics, which guides employees in carrying out their job professionally and ethically (Ghazali, 2015). A code of ethics is essential as it implicitly limits unethical behaviors and is intended to guide people in ambiguous situations (Pflugrath, Martinov-Bennie, \& Chen, 2007). In a corporation, a code of ethics is the foundation of ethics programs, and its contents could be critical in the development of a culture of ethics (Singh, 2015). The absence of a code of ethics, therefore, may indicate that management did not consider the code of ethics and ethical behavior essential (Adams et al., 2001). The code of ethics was designed to guide companies to become more socially responsible, provide guidelines for employees' behavior, improve company management, comply with government guidelines, and establish a better corporate culture (Cleek \& Leonard, 1998). The company implements the code of ethics and uses it as a tool to reduce ambiguity, promote ethical practices, and establish a strong ethical (Ibrahim, Angelidis, \& Tomic, 2009).

A code of ethics is a form of management accountability to shareholders to ensure that all employees in the company have worked ethically. The company is responsible to shareholders, and all employees' behavior must be aimed at maximizing shareholder value without breaking the law. Therefore, the purpose of an organization adopting a code of ethics is to satisfy its shareholders (Rodriguez-Dominguez et al., 2009). A code of ethics is a management effort to protect shareholders' interests and maximize their values. Meanwhile, (Wotruba, Chonko, \& Loe, 2001) stated that the important reason for the company to have and to implement the code of ethics is to look for legitimacy, protect shareholders' interest, and improve its reputation to increase public trust. 


\author{
Khasanah \& Sholihin \\ Code of Ethics, Clawback Incentive Schemes, and Personal Value...
}

Garegnani et al. (2015) stated that a code of ethics has high quality if there is a preface by top management in which the relationship between shareholders covered and regulated in the code of ethics includes the requirement to produce appropriate financial information for shareholders. To achieve a high-quality code of ethics, involvement of various parties is required, especially of the top management, and commitment to ethical programs (Garegnani et al., 2015). Other stakeholders, such as shareholders, consumers, suppliers, competitors, society, government, and other interest groups, also have the moral right to participate in the process of making ethical codes (Schwartz, 2002).

A code of ethics was created as a guide for organization members to do their tasks. It was an appropriate mechanism to encourage responsible behavior (RodriguezDominguez et al., 2009). The increasing number of companies having the code of ethics (Chen et al., 2016) is followed by the growing research about the effectiveness of the code of ethics for members' behavior in the organization. Several studies showed that the code of ethics is a potential factor that can influence ethical behavior (McCabe et al., 1996; Rich et al., 1990; Schwartz, 2002).

Previous studies of Booth and Schulz (2004), Chen et al. (2016), and Lucyanda and Sholihin (2016) showed that the code of ethics has an essential role in directing ethical behavior of employees to achieve company's goal, including preventing intention to behave opportunistically. A high-quality code of ethics in organizations would play a role in constraining potential opportunistic behavior (Chen et al., 2016). The instrumental perspective in compliance theory assumes that individuals shape their behavior in response to changes in impulses and penalties associated with the laws (Tyler, 1990). In order to achieve the effectiveness of the code of ethics, it must be supported by clear sanctions (Booth \& Schulz, 2004). Sanctions can be used as a deterrent to unethical actions (Adams et al., 2001) hence individuals have a strong tendency to avoid behavior contradicting or violating the code of ethics. Conversely, if the code of ethics is not supported by clear and strict sanctions, it is unlikely that it will be effective. Company members know that the code of ethics functions as guidance to behave, but they still have the freedom to behave in any way, as long as there are no sanctions. The code of ethics, therefore, will not have a deterrent effect on offenders. Meanwhile, the absence of the code of ethics means the company does not have guidelines for its members to behave ethically, including avoiding opportunistic behavior intention, such as earnings management. Earnings management intention may increase when there is no code of ethics, or there is a code of ethics but without sanctions. Thus, the following hypotheses are tested.

$\boldsymbol{H}_{1 a}$ : Individuals will tend to have earnings management intention when there is no code of ethics, compared to when there is a code of ethics with sanctions.

$\boldsymbol{H}_{1 b}$ : Individuals will tend to have earnings management intention when there is no code of ethics, compared to when there is a code of ethics without sanctions. 
$\boldsymbol{H}_{1 c}$ : Individuals will tend to have earnings management intention when there is a code of ethics without sanctions, compared to when there is a code of ethics with sanctions.

\section{Incentive Schemes}

Incentive compensation is one of three components of the manager's total compensation package (Anthony \& Govindarajan, 2007). An incentive is used by organizations to ensure employees' commitment to suit organizational goals (Chenhall, 2003; Crocker \& Slemrod, 2007). Initially, the clawback policy was voluntary. Between 2003 until early 2010, more than 300 firms in the Fortune 1000 and more than 70 in the Fortune 100 adopted clawback (Chen, Greene, \& Owers, 2015). Furthermore, clawback had become mandatory after the publication of the Dodd-Frank Act 2010 (Hirsch, Reichert, \& Sohn, 2017). The clawback policy stated in the Dodd-Frank Act, a financial regulation law in the United States, requires public firms to adopt policies encouraging certain types of recovery from overpayments made by executives based on financial results that turned out to be false and require restatement (Fried \& Shilon, 2011).

Clawback is defined as recovering the CEO and CFO's incentive compensation if the restatement of accounting is attributed to intentional misconduct (Iskandar-Datta \& Jia, 2013). There are several benefits if a company adopts a clawback policy. Clawback is expected to improve compensation arrangements in public companies (Fried \& Shilon, 2011). It can also assign the board on the side that potentially protects the company's assets in investor's interests so that it can align shareholders' interests (Addy, Chu, \& Yoder, 2014; Brown, Davis-Friday, Guler, \& Marquardt, 2015). Moreover, the important reason for adopting the clawback policy is that without it, the executives will continue to receive compensation despite poor performance (Dehaan, Hodge, \& Shevlin, 2013).

Previous studies, such as Beaudoin et al. (2015); Jouber and Fakhfakh (2014); Laux and Laux (2009); and Reitenga et al. (2002), have examined the relationship between incentive schemes and earnings management. Higher incentive equity encourages managers to conduct earnings management (Cheng \& Warfield, 2005). CEO, whose overall compensation is more sensitive to the company's stock price, will cause a higher level of earnings management (Bergstresser \& Philippon, 2006). Managers often conduct unethical behaviors for personal gains, such as earnings management. Shareholders set appropriate incentives for managers to ensure that managers will not take certain actions that can harm shareholders (Jensen \& Meckling, 1976). Therefore, the incentive scheme is required to mitigate earnings management intention. One of the appropriate incentive schemes in mitigating earnings management is clawback, namely incentives containing penalties for misstatements in financial statements. Clawback has been found able to reduce financial misstatements (Pyzoha, 2015), increase investor's confidence on earnings information (Chan et al., 2015), decrease in fraud risk (Fung, Raman, Sun, \& Xu, 2015), and increase accounting quality and reduce audit risk (Chan et al., 2012). 


\author{
Khasanah \& Sholihin \\ Code of Ethics, Clawback Incentive Schemes, and Personal Value...
}

This study compared clawback and bonus-only incentive schemes. In the bonus-only scheme, individuals would be given bonuses without the bonus-return penalty for misstatements in financial statements. Meanwhile, clawback has a restraining effect on risk-taking compared to bonus-only contracts (Hirsch et al., 2017). Prospect theory stated that individuals would tend to avoid risks in choices involving specific gain (positive domains) and take risks in choices involving certain losses (negative domains) (Kahneman \& Tversky, 1979). Individuals will likely have a higher tendency to avoid earnings management when given a clawback incentive because it provides a penalty if it was proven to misstate financial statements. In other words, individuals will be less motivated to manipulate earnings in financial statements if the incentive provided is in the form of clawback rather than bonus-only. Thus, hypothesis 2 is formulated as follows.

$\mathrm{H}_{2}$ : Individuals will tend to have earnings management intention when given incentives in the form of bonus-only compared to when given incentives in the form of clawback.

\title{
Personal Values
}

Values are the center of individuals' thinking, and therefore play a role in the formation of attitudes and the implementation of intentional behavior in many situations and issues (Rokeach, 1973). Value is used to guide and encourage individuals to behave in a way that is ethical or unethical (Pohling, Bzdok, Eigenstetter, Stumpf, \& Strobel, 2016). Value is necessary to identify specific personal values in accordance with the accounting profession (Shafer et al., 2001) as it will ease them to behave ethically in the work environment.

Scott (1965) developed scales that could be used to measure personal value. In this study, the measurement of personal values referred to personal value instruments adopted from Akaah and Lund (1994). They chose four sub-scales, namely intellectualism, honesty, self-control, and religiousness. They were chosen because they seemed relevant to the study topic on ethics (Akaah \& Lund, 1994). The explanation of these sub-scales in the instrument is as follows (Alleyne, Cadogan-McClean, \& Harper, 2013).

1. Intellectualism: Individuals have the ability for understanding, thinking, and reasoning.

2. Honesty: Conditions of being trustworthy, genuine, and sincere

3. Self-control: Ability to hold back or control individuals' feelings, emotions, and reactions

4. Religiousness: Belief in worship or obedience to the power considered to have control over human destiny

Decision making in business and organizational contexts are also determined by the personal value (Shafer et al., 2001). Therefore, this study examined the interaction effect between the code of ethics and personal value on earnings management 
intention. (Ferrell \& Gresham, 1985) stated that individual factors (one of which is value) might interact with organizational factors to influence individuals involved in an ethical/unethical decision-making dilemma. The decision-making process is complex because it involves individual, organizational, and contextual issues (Jones, 1991). If an organization has facilitated individuals to behave ethically by creating a conducive ethical climate, it will not be optimal if individuals' factors do not support it.

Several previous studies had shown that the code of ethics influenced ethical behavior decisions (Adams et al., 2001; McCabe et al., 1996; Schwartz, 2002). Individuals will avoid having unethical opportunistic behavior when an organization/company has a code of ethics. The code of ethics clearly states that there are prohibitions on opportunistic behavior, which can damage professionalism. Moreover, individuals will be given sanctions when proven to have violated the code of ethics. It will be strengthened by higher personal values (intellectualism, honesty, self-control, and religiousness) they have. The existence of organizational factors in the form of the code of ethics and individual factors, namely high personal value, will increasingly encourage individuals not to have earnings management intention. Conversely, although there is a code of ethics in the organization, without sanctions, or even there is no code of ethics regulating the prohibition of opportunistic behavior, there is likely to be an increase in earnings management intention. Brief, Dukerich, Brown, \& Brett (1996) argued that personal and organizational factors might impact the probability of individuals engaged in fraudulent financial reporting. Thus, hypothesis 3 is formulated as follows.

$\boldsymbol{H}_{3}$ : Personal values moderate the relationship between the code of ethics and earnings management intention.

Personal values are one of many variables that potentially influence the moral perception of agents on the interests of shareholders involved (Shafer et al., 2001). Values differ from other personal attributes because they are inherent and encourage individuals to behave in certain situations (Adams, Licht, \& Sagiv, 2011). Previous studies did not examine the joint effect between incentive schemes and personal values on earnings management intention (Beaudoin et al., 2015; Brief et al., 1996). This study suspects that an incentive scheme without penalty for returning incentives due to misstatements in financial reporting, and the low personal value of individuals will encourage and strengthen them to have higher earnings management intention. Individuals tend to pursue their interests, namely bonuses, based on achievement of performance. The absence of penalties for returning incentives due to misstatements in the financial statements will further encourage individuals to have a higher intention of earnings management. Thus, hypothesis 4 is formulated as follows.

$\boldsymbol{H}_{4}$ : Personal values moderate the relationship between incentive schemes and earnings management intention. 


\author{
Khasanah \& Sholihin \\ Code of Ethics, Clawback Incentive Schemes, and Personal Value...
}

\title{
Research Method
}

This study applied an experimental research design to test the hypotheses. This design is widely used to show causality relationships (Sekaran \& Bougie, 2013). A 3x2 factorial experiment was used in this study. The code of ethics variable was manipulated into three manipulations, namely "code of ethics with sanctions", "code of ethics without sanctions", and "without code of ethics" in accordance with instruments developed by Lucyanda and Sholihin (2016). The incentive scheme variable was manipulated by providing incentives to participants in the form of "bonus-only" and "clawback" (Hirsch et al., 2017). Meanwhile, this study did not manipulate the personal value variable as it was measured using four sub-scales of the personal values scale (PVS) developed by Scott (1965). The reason for using the PVS was because it was relevant to this research topic on ethics (Akaah \& Lund, 1994).

The subjects of this study were undergraduate and postgraduate students of the Accounting Program, Faculty of Economics and Business from a public university in Yogyakarta, Indonesia ${ }^{1}$. The research subjects were students as surrogates of practitioners because research assignments given did not require professional experience. The subject received treatment and assigned randomly into 6 groups. Randomization was used to ensure that subjects have been placed in the experimental or control group randomly without regarding inherent factors of the subject (Nahartyo \& Utami, 2016).

The experimental tasks are as follows. First, subjects were asked to fill out the consent form as a research participant. Second, the subjects read information about their role as finance director in a manufacturing company. Third, subjects were asked to read on an experimental case and fill in response to reject or support to do earnings management. Then, they answered some manipulation check questions. Manipulation checks were performed to ascertain that all of the subjects have received manipulation with measures and forms designed by the researcher (Nahartyo \& Utami, 2016). For the code of ethics treatment, this study asked questions "Does Semen Baturatu Company has a code of ethics?", "Does Semen Baturatu's code of ethics arrange sanctions for ethical violations committed by the board of directors, employees, and company representatives?". For incentive schemes, this study asked a question, "Must you return a bonus incentive of $80 \%$ if your company is proven to have made a misstatement in the financial statement?" If the participants' answers were not in accordance with the treatments given, then the answers would be excluded from the data analysis. It showed that participants could not internalize the treatments provided. Finally, subjects were asked to fill out the questionnaire and complete the demographic data.

The dependent variable was the earnings management intention. Earnings management intention is intent opportunistic behavior committed by individuals to increased earnings reported in financial statements to receive personal gain. A modified Clikeman

\footnotetext{
${ }^{1}$ ANCOVA test showed that student's level (undergraduate vs postgraduate) did not significantly affect earnings management $(p=0,688)$
} 


\author{
Khasanah \& Sholihin \\ Code of Ethics, Clawback Incentive Schemes, and Personal Value...
}

and Henning (2000)'s instrument was used to measure this variable. This study made some modifications to this instrument to adjust to an Indonesian company context. In Clikeman and Henning (2000)'s instrument, participants were assumed to be as vice president in the manufacturing company while this study substituted the role of participants as financial director. Then, the phrase "for winter days" in "Your company is closed for the last two weeks of December this year for winter days" was omitted to adjust to the condition in Indonesia. This variable was measured using the 7-point scale ( 1 is "very opposed to delays" and 7 is "strongly supported delays").

The independent variables included the code of ethics and incentive schemes. The code of ethics is guidance about norms for behavior and has been agreed upon by organization members. This study used Lucyanda and Sholihin (2016)'s instrument to manipulate the code of ethics variable. It consisted of three manipulations, namely "code of ethics with sanctions", "code of ethics without sanctions", and "without code of ethics". The incentive scheme is an incentive designed by companies to motivate employees with goals congruence and generally in financial form. This variable was manipulated by providing information on bonus-only and clawback incentives to participants, such as the manipulation of the experimental study of Hirsch et al. (2017). Bonus-only manipulation showed that bonus is given based on financial targets, such as profits. Meanwhile, clawback manipulation showed bonus information along with the penalty in the form of returning $80 \%$ of the total bonus for misstatements in financial statements. The amount of bonus return was based on Pyzoha (2015)'s experimental manipulation, which was $80 \%$ of the total bonus received.

The moderating variable was personal value. Personal values are individual beliefs about certain standards, which can be used to make ethical decisions. This study used the PVS instrument adopted from Akaah and Lund (1994)'s study to measure the variable. Their study used personal values consisting of four sub-scales (intellectualism, self-control, honesty, and religiousness) developed by Scott (1965). Participants were asked to provide their evaluation of 23 statements on the 7-point scale, ranging from "very opposed to delays" (code 1) and "strongly supported delays" (code 7).

Data analysis consisted of descriptive analysis, validity and reliability test, assumption of analysis of variance (ANOVA), analysis of covariate (ANCOVA), and hypothesis testing using two-way ANOVA. Descriptive statistics consisted of sum, average, and standard deviation of data. A business ethics expert's assessment used in this study aims to increase instrument validity. Meanwhile, to test the construct validity of personal value instruments, confirmatory factor analysis (CFA) was used. A reliability test was carried out to show the consistency of the instrument.

Before testing hypotheses 1 and 2, ANOVA assumptions consisting of normality, homogeneity, and randomization were carried out. Moreover, this study also conducted an ANCOVA to examine the relationship between individuals' demographic characteristics on the dependent variable. Test of hypotheses 1 and 2 was conducted by the two-way ANOVA. For hypothesis 1 , if the results of the two-way ANOVA were significant, further analysis was required to determine the significance of differences in 
each group. It could be done by the posthoc test. Meanwhile, the two-way ANOVA was also used to test hypotheses 3 and 4 , aiming to examine the interaction effect.

\section{Results and Discussion}

\section{Manipulation Check and Participant Characteristics}

Before conducting experiments, this study conducted a pilot test to 53 students from the Master of Science in Accounting Program, Faculty of Economics and Business from a public university in Yogyakarta, Indonesia. Of 53 participants, 83\% (44 participants) completed all of the questions and statements in experimental material and passed manipulation check. The results showed that the pilot test was quite good because most participants had understood well the research instrument given.

A total of 95 participants took part in this experiment. Participants who succeeded in answering all of the experimental materials were $94.67 \%$ (91 participants), and 5.33\% (4 participants) failed to answer instruction in experimental materials. Thus, 91 participants could be further analyzed. Furthermore, manipulation checks were conducted to ensure that the participants have internalized to the treatment given. Of the 91 participants, $8.02 \%$ ( 8 participants) failed, resulting in $91.98 \%$ ( 83 participants) passing the manipulation check.

Table 1 Participants' Demographic Characteristics

\begin{tabular}{lcc}
\hline & Total & Percentage (\%) \\
\hline Gender & & 41 \\
$\quad$ Male & 34 & 59 \\
Female & 49 & 100 \\
$\quad$ Total & 83 & \\
Age & & 71.1 \\
$\quad \leq 22$ years & 59 & 28.9 \\
\hline $23-35$ years & 24 & 100 \\
$\quad$ Total & 83 & 69.9 \\
Study Program & & 30.1 \\
$\quad$ Undergraduate & 58 & 100 \\
$\quad$ Postgraduate (Master of Accounting) & 25 & 94 \\
$\quad$ Total & 83 & 6 \\
Work Experience & & 100 \\
\hline 0-5 years & 78 & \\
5-10 years & 5 & \\
$\quad$ Total & 83 & \\
\hline
\end{tabular}

The participants consisted of 34 male (41\%) and 49 female (59\%) students. Participants had an age range of $\leqslant 22$ years were 59 (71.1\%), and $23-35$ years were 24 (28.9\%) students. Furthermore, participants were students taking the undergraduate Accounting Program and postgraduate Accounting Program (Master of Accounting). Of the 83 participants, 58 (69.9\%) were undergraduate students, and 25 (30.1\%) were 
postgraduate students. Seventy-eight (78\%) participants had 0-5 years of work experience, and 5 (6\%) participants had work experience of 5-10 years. Table 1 shows the participants'demographic characteristics.

\section{Hypotheses Testing}

Before testing the hypotheses, this study examined the validity and reliability of the personal value instrument. This study also conducted the ANOVA assumption and ANCOVA test. Based on CFA results, KMO-MSA and Bartlett values of the sphericity test were 0.674 (more than 0.50 ) and 0.000 (significant), respectively. The factor interpretation used a factor rotation. The rotated component matrix results formed four factors, and six items were excluded from the analysis for having a loading factor under 0.50 . Hence, 17 other items proven valid statistically. Meanwhile, constructing items of the personal value resulted in Cronbach's coefficient alpha of 0.780 (more than 0.60). Thus, it can be said that the personal value instrument was reliable.

The ANOVA assumption consisted of normality, homogeneity, and randomization test. The normality test showed a significance value of 0.149 (more than 0.05 ) that the residual was normally distributed. Levene test result showed that the significance of variance homogeneity was 0.072 (more than 0.05 ), indicating that samples had the same variance. Whereas randomization results showed that all of the demographic characteristics had Person Chi-Square values above 0.05, thus providing evidence that randomization had been carried out. Moreover, this study also conducted an ANCOVA test by examining the demographic characteristics of the dependent variable. Based on the results, all of the demographic characteristics, including gender, age, study program, and work experience, did not significantly influence earnings management intention (significance value above 0.05 ).

Table 2 Descriptive Statistics

\begin{tabular}{|c|c|c|c|c|c|}
\hline & & \multicolumn{3}{|c|}{ Codes of ethics } & \multirow[t]{2}{*}{ Total } \\
\hline & & $\begin{array}{l}\text { Code of ethics } \\
\text { with sanctions }\end{array}$ & $\begin{array}{c}\text { Code of ethics } \\
\text { without } \\
\text { sanctions }\end{array}$ & $\begin{array}{l}\text { Without code of } \\
\text { ethics }\end{array}$ & \\
\hline \multirow{6}{*}{$\begin{array}{l}\text { Incentive } \\
\text { Scheme }\end{array}$} & Bonus- & $(N=13)$ & $(N=14)$ & $(N=14)$ & $(N=41)$ \\
\hline & only & Mean $=2.15$ & Mean $=4.50$ & Mean $=3.71$ & Mean $=3.49$ \\
\hline & & $\begin{array}{c}\text { Std. Dev }= \\
0.899\end{array}$ & $\begin{array}{c}\text { Std. Dev }= \\
1.557\end{array}$ & Std. Dev = 1.437 & $\begin{array}{c}\text { Std. Dev }= \\
1.630\end{array}$ \\
\hline & Claw- & $(N=15)$ & $(N=13)$ & $(N=14)$ & $(N=42)$ \\
\hline & back & Mean $=2.87$ & Mean $=3.08$ & Mean $=4.07$ & Mean $=3.33$ \\
\hline & & $\begin{array}{c}\text { Std. Dev = } \\
1.598\end{array}$ & $\begin{array}{c}\text { Std. Dev }= \\
1.498\end{array}$ & Std. Dev = 1.685 & $\begin{array}{c}\text { Std. Dev = } \\
1.648\end{array}$ \\
\hline \multirow[t]{3}{*}{ Total } & & $(N=28)$ & $(N=27)$ & $(N=28)$ & $(N=83)$ \\
\hline & & Mean $=2.54$ & Mean $=3,81$ & Mean $=3.89$ & Mean $=3.41$ \\
\hline & & $\begin{array}{c}\text { Std. Dev }= \\
1.347\end{array}$ & $\begin{array}{c}\text { Std. Dev }= \\
1.665\end{array}$ & Std. Dev = 1.548 & $\begin{array}{c}\text { Std. Dev }= \\
1.631\end{array}$ \\
\hline
\end{tabular}

Table 2 shows the descriptive statistics of each group. Overall, 41 participants received a bonus-only incentive scheme treatment with an average earnings management 
intention, and standard deviations were 3.49 and 1.630, respectively. Forty-two participants obtained a clawback incentive scheme. The average earnings management intention on this incentive scheme was 3.33, with a standard deviation of 1.648 . Meanwhile, 28 participants received a code of ethics with sanctions treatment. The average earnings management intention and standard deviation were 2.54 and 1.347, respectively. Participants having a code of ethics without sanctions treatment had an average value of earnings management intention of 3.81, with a standard deviation of 1.665. The total participants receiving this treatment was 27. Participants receiving without a code of ethics treatment showed that the average value of earnings management intention was 3.89. The standard deviation value was 1.548 . The number of participants receiving this treatment was 28 .

The results of the two-way ANOVA and post-hoc tests are shown in Table 3 and 4, respectively.

Table 3 Result of Two-Way ANOVA

\begin{tabular}{lcc}
\multicolumn{1}{c}{ Variable } & $F$ & Sig. \\
\hline Code of Ethics & 7.651 & 0.001 \\
Incentive Schemes & 0.132 & 0.718 \\
R square $=0.231$ (Adjusted R Square = 0.181) & & \\
\hline
\end{tabular}

A two-way ANOVA was used to test hypotheses 1 and 2, resulting in the F-value $=7.561$ and $p$-value $=0.001$. Furthermore, post-hoc tests were conducted to find out which groups differ significantly. The post-hoc results showed significant differences in earnings management intention between without a code of ethics group and code of ethics with sanctions group. The average difference between these groups was 1.36, with a significance value of 0.003 . Thus, hypothesis 1 a was supported. The post-hoc results also showed differences in earnings management intention made by groups receiving without a code of ethics and a code of ethics without sanctions treatment. The average difference in earnings management intention between these groups was 0.08 , withasignificance level of 0.979 . The difference was statistically insignificant. Therefore, hypothesis $1 \mathrm{~b}$ was not supported.

Table 4 Result of Post-Hoc Tests

\begin{tabular}{|c|c|c|c|c|}
\hline & Treatments & Treatments & $\begin{array}{c}\text { Mean } \\
\text { Difference }\end{array}$ & Sig. \\
\hline \multirow{6}{*}{$\begin{array}{c}\text { Tukey } \\
\text { Test }\end{array}$} & \multirow{2}{*}{$\begin{array}{l}\text { Without code } \\
\text { of ethics }\end{array}$} & Code of ethics without sanctions & 0.398 & 0.08 \\
\hline & & Code of ethics with sanctions & 0.394 & $1.36^{*}$ \\
\hline & \multirow{2}{*}{$\begin{array}{l}\text { Code of ethics } \\
\text { without } \\
\text { sanctions }\end{array}$} & Without code of ethics & 0.398 & -0.08 \\
\hline & & Code of ethics with sanctions & 0.398 & $1.28^{*}$ \\
\hline & \multirow{2}{*}{$\begin{array}{l}\text { Code of ethics } \\
\text { with sanctions }\end{array}$} & Without code of ethics & 0.394 & $-1.36^{*}$ \\
\hline & & Code of ethics without sanctions & 0.398 & $-1.28^{*}$ \\
\hline
\end{tabular}

Moreover, this result also showed a significant difference between the code of ethics without the sanctions group and the code of ethics with the sanctions group. The average difference between these groups was 1.28 , with a significant value of 0.005 . 
Therefore, hypothesis 1c was supported. Furthermore, the two-way ANOVA test for hypothesis 2 stated that the group of clawback and bonus-only showed insignificant results (F-value $=0.132$ and $p$-value $=0.718$ ). Therefore, hypothesis 2 was not supported.

The result of the two-way ANOVA for hypotheses 3 is presented in the Table 3 . The twoway ANOVA was also used to determine the moderating effect of personal value variables on the relationship between the code of ethics and incentive schemes with earnings management intention (hypotheses 3 and 4). The two-way ANOVA test results provided evidence that the interaction of the code of ethics and personal values showed insignificant value ( $p$-value $=0.174)$. Therefore, it could be concluded that the personal value variable was not a moderating variable. Thus, hypothesis 3 was not supported.

Table 5 Result of Two-Way ANOVA

\begin{tabular}{ccc}
\hline \multicolumn{1}{c}{ Variable } & $F$ & Sig. \\
\hline Code of Ethics * Personal Value & 1.788 & 0.174 \\
R square $=0.194$ (Adjusted R Square = 0.143) & & \\
\hline
\end{tabular}

Meanwhile, the interaction of incentive schemes and personal values showed insignificant value ( $p$-value $=0.220$ ). Hence, it could be concluded that the personal value variable was not a moderating variable. Thus, hypothesis 4 was not supported. The result of the two-way ANOVA for hypothesis 4 is shown in Table 6.

Table 6 Result of Two-Way ANOVA

\begin{tabular}{lcc}
\hline \multicolumn{1}{c}{ Variable } & $F$ & Sig \\
\hline Incentive Schemes * Personal Value & 1.529 & 0.220 \\
R square $=0.045$ (Adjusted R Square = 0.010) & & \\
\hline
\end{tabular}

\section{Code of Ethics and Earnings Management Intention}

The statistic result showed that $\mathrm{H}_{1 \mathrm{a}}$ was supported. It indicated that when individuals were not given the code of ethics, they would have a higher earnings management intention compared to those given the code of ethics with sanctions. The individuals tended to avoid unethical behavior due to strict sanctions. This result confirmed the compliance theory proposed by Tyler (1990). The instrumental perspective in this theory assumed that individuals shaped their behavior in response to changes impulses and penalties associated with the laws (Tyler, 1990). This result was also supported by a study conducted by Lucyanda and Sholihin (2016), showing that individuals supported by a code of ethics with sanctions would see budgetary slack as unethical behavior compared to those who did not get a code of ethics.

The statistic result implied that $\mathrm{H}_{1 b}$ was not supported. There was a slight difference in earnings management intention between a group not given a code of ethics and a group given a code of ethics without sanctions. This result was consistent with Ford, Gray, and Landrum (1982)'s study, discovering slight differences in the decision to behave between two groups, namely group with the code of ethics and without the code of ethics. Their study concluded that the code of ethics was mostly ineffective. No sanctions for violations caused the ineffectiveness of the code of ethics. It was in 


\author{
Khasanah \& Sholihin \\ Code of Ethics, Clawback Incentive Schemes, and Personal Value...
}

accordance with a study conducted by Booth and Schulz (2004)stating that to achieve the effectiveness of the code of ethics, codes must be supported by clear sanctions.

The statistic result showed that $\mathrm{H}_{1 c}$ was supported. It indicated that sanctions in the code of ethics were effective means of mitigating earnings management intention. Garegnani et al. (2015) stated that the effectiveness of the code of ethics would weaken due to the absence of adequate compliance procedures and policies to reduce unethical and illegal actions. An important procedure and policy that should be considered by the organization were feedback in the form of sanctions for violations. This result confirmed an instrumental perspective in compliance theory in which individuals shaped their behavior in response to changes impulses and penalties associated with the laws (Tyler, 1990).

\title{
Incentive Schemes and Earnings Management Intention
}

Based on statistic results, a group of a clawback incentive scheme had a smaller earnings management intention than the bonus-only incentive scheme group. However, differences in earnings management intention of the two groups showed insignificant results. Thus $\mathrm{H}_{2}$ was not supported. It indicated that individuals did not feel a dilemma when the incentive scheme was resolved with a refund penalty for a misstatement in financial statements. This hypothesis was not supported since the purpose of this study differed from previous ones. For example, a study by Chan et al. (2015) compared the effects of a clawback policy on substitution of accrual manipulation with real transaction management. Meanwhile, this study only examined the effect of clawback on a type of earnings management, namely real transaction earnings in the form of operating decisions. Earnings management in operating decisions had a higher tolerance than earnings management in the form of accounting manipulation (Fischer \& Rosenzweig, 1995). Thus, the effect of the bonus return penalty for a misstatement in the financial statements was unlikely to differ significantly in the behavior of real earnings management compared to the absence of a bonus return (bonus only).

\section{The Interaction between the Code of Ethics, Incentive Schemes and Personal Value to Earnings Management Intention}

Based on the statistic results, $\mathrm{H}_{3}$ and $\mathrm{H}_{4}$ were not supported. It means that personal values did not moderate the relationship between the code of ethics and incentive schemes with earnings management intention. According to the synthesis of ethical decision-making models by Jones (1991), ethical decision making is a contingent issue involving various factors, such as environment (social, cultural, economic, and organizational), individual, situation, opportunity, and others. It showed that not only individual factors as moderating, but there were also other moderating factors, namely the situation. Situational factors include elements of job context, organizational culture, and characteristics of work (Jones, 1991). Even though individuals have been given a code of ethics, specific incentive schemes, and have high personal values, they would still consider certain situations in the work environment when facing ethical decisionmaking dilemmas. For example, situations when getting superiors or co-workers' 


\author{
Khasanah \& Sholihin \\ Code of Ethics, Clawback Incentive Schemes, and Personal Value...
}

pressures also have an important role in determining individuals' intention to behave in a certain way.

\title{
Conclusions
}

This study aimed to examine the role of the code of ethics and incentive schemes in mitigating earnings management intention and also to examine the influence of personal values toward the relationship of the code of ethics and incentive schemes with earnings management. This study provided empirical evidence that the code of ethics could mitigate individuals' earnings management intention. Therefore, the code of ethics was essential to consider to prevent opportunistic behavior in the company. It would be more effective when it was complemented by clear and strict sanctions. Sanctions would give a deterrent effect on violators. Conversely, the absence of sanctions would likely cause company members to ignore the code of ethics as there was no feedback. However, this study did not find significant differences between clawback and bonus-only incentive schemes on earnings management intention. This study only examined the effect of a clawback incentive scheme on a type of earnings management, namely real transaction earnings in the form of operating decisions. Therefore, a clawback incentive scheme could not have a significant impact on the type of earnings management used in this study. The next finding was that personal values did not moderate the relationship between the code of ethics and incentive schemes on earnings management intention. In ethical decision making, individuals did not only depend on individuals and organizational factors but involved complex factors, such as situation and context.

This study has several limitations. First, it only examined earnings management in the form of real earnings management as the operating decisions. It is possible to generalize the topic of earnings management. Therefore, further research can examine earnings management practice as a whole. Second, most of the data collection was carried out after class, causing participants to lack concentration as they were tired of the lessons in class. Further research can consider more appropriate experiment times so that participants can concentrate more on going research.

\section{References}

Adams, J. S., Tashchian, A., \& Shore, T. H. (2001). Codes of Ethics as Signals for Ethical Behavior. Journal of Business Ethics, 29(3), 199-211. https://doi.org/10.1023/a:1026576421399

Adams, R. B., Licht, A. N., \& Sagiv, L. (2011). Shareholders and Stakeholders: How Do Directors Decide?. Strategic Management Journal, 32 (12), 1331-1355. https://doi.org/10.1002/smj.940

Addy, N., Chu, X., \& Yoder, T. (2014). Voluntary Adoption of Clawback Provisions, Corporate Governance, and Interlock Effects. Journal Accounting Public Policy, 33(2), 167-189. https://doi.org/10.1016/i.jaccpubpol.2013.12.001 
Akaah, I. P., \& Lund, D. (1994). The Influence of Personal and Organizational Values on Marketing Professionals' Ethical Behavior. Journal of Business Ethics, 13(6), 417-430. https://doi.org/10.1007/bf00881450

Alleyne, P., Cadogan-McClean, C., \& Harper, A. (2013). Examining Personal Values and Ethical Behaviour Perceptions between Accounting and Non-accounting Students in the Caribbean. The Accounting Educators' Journal, 23, 47-70. Retrieved from https://www.researchgate.net/publication/260506903 Examining_Personal Values and Ethical Behaviour_Perceptions between_Accounting_and_Nonaccounting Students in the Caribbean

Anthony, R. N., \& Govindarajan, V. (2007). Management Control System. New York: The McGraw-Hill Companies, Inc.

Beaudoin, C. A., Cianci, A. M., \& Tsakumis, G. T. (2015). The Impact of CFOs' Incentives and Earnings Management Ethics on their Financial Reporting Decisions: The Mediating Role of Moral Disengagement. Journal of Business Ethics, 128(3), 505-518. https://doi.org/10.1007/s10551-014-2107-x

Bergstresser, D., \& Philippon, T. (2006). CEO Incentives and Earnings Management. Journal of Financial Economics, 80(3), 511-529. https://doi.org/10.1016/j.jfineco.2004.10.011

Booth, P., \& Schulz, A. K.-D. (2004). The Impact of an Ethical Environment on Managers' Project Evaluation Judgments Under Agency Problem Conditions. Accounting, Organizations and Society, 29 (5-6) 473-488. https://doi.org/10.1016/s03613682(03)00012-6

Brief, A. P., Dukerich, J. M., Brown, P. R., \& Brett, J. F. (1996). What's Wrong with the Treadway Commission Report? Experimental Analyses of the effects of Personal Values and Codes of Conduct on Fraudulent Financial Reporting. Journal of Business Ethics, 15(2), 183-198. https://doi.org/10.1007/bf00705586

Brooks, L. J. (1989). Corporate Codes of Ethics. Journal of Business Ethics, 8(2/3), 117-129. https://doi.org/10.1007/bf00382576

Brown, A. B., Davis-Friday, P. Y., Guler, L., \& Marquardt, C. (2015). M\&A Decisions and US Firms' Voluntary Adoption of Clawback Provisions in Executive Compensation Contracts. Journal of Business Finance \& Accounting, 42(1 \& 2), 237-271. https://doi.org/10.1111/ibfa.12111

Burns, N., \& Kedia, S. (2006). The Impact of Performance-Based Compensation on Misreporting. Journal of Financial Economics, 79(1), 35-67. https://doi.org/10.1016/i.jfineco.2004.12.003

Callen, J. L., Morel, M., \& Richardson, G. (2011). Do Culture and Religion Mitigate Earnings Management? Evidence from A Cross-Country Analysis. International Journal of Disclosure and Governance, 8(2), 103-121. https://doi.org/10.1057/jdg.2010.31

Chan, L. H., Chen, K. C. W., Chen, T. Y., \& Yu, Y. (2015). Substitution between Real and Accruals-Based Earnings Management after Voluntary Adoption of Compensation Clawback Provisions. The Accounting Review, 90(1), 147-174. https://doi.org/10.2308/accr-50862

Chan, L. H., Chen, K. C. W., Chen, T., \& Yu, Y. (2012). The Effect of Firm-initiated Clawback Provisions on Earnings Quality and Auditor Behavior. Journal of Accounting and Economics, 54(2-3), 180-196. https://doi.org/10.1016/i.jacceco.2012.05.001

Chen, C., Gotti, G., Kang, T., \& Wolfe, M. C. (2016). Corporate Codes of Ethics, National Culture, and Earnings Discretion: International Evidence. Journal of Business Ethics, 151 (1), 141-163. https://doi.org/10.1007/s10551-016-3210-y

Chen, M. A., Greene, D. T., \& Owers, J. E. (2015). The Costs and Benefits of Clawback Provisions in CEO Compensation. Review of Corporate Finance Studies, 4(1), 108-154. https://doi.org/10.1093/rcfs/cfu012 
Cheng, Q., \& Warfield, T. D. (2005). Equity Incentives and Earnings Management The Accounting Review, 80(2), 441-476. https://doi.org/10.2308/accr.2005.80.2.441

Chenhall, R. H. (2003). Management Control Systems Design Within Its Organizational Context: Findings from Contingency-Based Research and Directions for the Future. Accounting, Organizations and Society, 28(2-3), 27-168. https://doi.org/10.1016/s0361$\underline{3682(01) 00027-7}$

Cleek, M. A., \& Leonard, S. L. (1998). Can Corporate Codes of Ethics Influence Behavior? Journal of Business Ethics, 17(6), 619-630. https://doi.org/10.1023/a:1017969921581

Clikeman, P. M., \& Henning, S. L. (2000). The Socialization of Undergraduate Accounting Students. American Accounting Association, 15(1), 1-17. https://doi.org/10.2308/iace.2000.15.1.1

Cooper, D. R., \& Schindler, P. S. (2014). Business Research Methods. New York: McGraw-Hill Higher Education.

Crocker, K. J., \& Slemrod, J. (2007). The Economics of Earnings Manipulation and Managerial Compensation. The RAND Journal of Economics, 38(3), 698-713. https://doi.org/10.1111/i.0741-6261.2007.00107.x

Davidson, B. I., \& Stevens, D. E. (2013). Can a Code of Ethics Improve Manager Behavior and Investor Confidence? An Experimental Study. The Accounting Review, 88(1), 51-74. https://doi.org/10.2308/accr-50272

Dehaan, E., Hodge, F., \& Shevlin, T. (2013). Does Voluntary Adoption of a Clawback Provision Improve Financial Reporting Quality? Contemporary Accounting Research, 30(3), 1027-1062. https://doi.org/10.1111/i.1911-3846.2012.01183.x

Ferrell, O. C., \& Gresham, L. G. (1985). A Contingency Framework for Understanding Ethical Decision Making in Marketing. Journal of Marketing, 49(3), 87-96. https://doi.org/10.1177/002224298504900308

Fischer, M., \& Rosenzweig, K. (1995). Attitudes of Students and Accounting Practitioners concerning the Ethical Acceptabilityof Earnings Management. Journal of Business Ethics, 14(6), 433-444. https://doi.org/10.1007/bf00872085

Ford, R., Gray, B., \& Landrum, R. (1982). Do Organizational Codes of Conduct Really Affect Employees' Behaviour? Management Review, 71(6), 53.

Fried, J. M., \& Shilon, N. (2011). Excess Pay and Dodd-Frank Clawback. Director Notes, 3(20), 1-8. Retrieved from https://www.sec.gov/comments/s7-12-15/s71215-68.pdf

Fung, S. Y. K., Raman, K. K., Sun, L., \& Xu, L. (2015). Insider Sales and the Effectiveness of Clawback Adoptions in Mitigating Fraud Risk. Journal of Accounting and Public Policy, 34 (4), 417-436. https:// doi.org/10.1016/i.jaccpubpol.2015.04.002

Garegnani, G. M., Merlotti, E. P., \& Russo, A. (2015). Scoring Firms' Codes of Ethics: An Explorative Study of Quality Drivers. Journal of Business Ethics, 126(4), 541-557. https://doi.org/10.1007/s10551-013-1968-8

Gavious, I., Segev, E., \& Yosef, R. (2012). Female Directors and Earnings Management in High - Technology Firms. Pacific Accounting Review, 24(1), 4-32. https://doi.org/10.1108/01140581211221533

Ghazali, N. A. M. (2015). The Influence of a Business Ethics Course on Ethical Judgments of Malaysian Accountants. Journal of Asia Business Studies, 9(2), 147-161. https://doi.org/10.1108/JABS-06-2014-0042

Greenfield, A. C., Norman, C. S., \& Wier, B. (2008). The Effect of Ethical Orientation and Professional Commitment on Earnings Management Behavior. Journal of Business Ethics, 83(3), 419-434. https:// doi.org/10.1007/s10551-007-9629-4

Hirsch, B., Reichert, B. E., \& Sohn, M. (2017). The Impact of Clawback Provisions on Information Processing and Investment Behaviour. Management Accounting Research, 37, 1-11. https://doi.org/10.1016/j.mar.2016.12.001 
Hossain, D. M., Karim, M. K. A., \& Eddine, C. H. (2014). Earnings Management and Islam. Labuan e-Journal of Muamalat and Society, 8, 87-97. https://www.researchgate.net/publication/324919523 EARNINGS MANAGEME NT AND_ISLAM

Ibrahim, N., Angelidis, J., \& Tomic, I. M. (2009). Managers' Attitudes Toward Codes of Ethics: Are There Gender Differences? Journal of Business Ethics, 90(3), 343-353. https://doi.org/10.1007/s10551-010-0428-y

Iskandar-Datta, M., \& Jia, Y. (2013). Valuation Consequences of Clawback Provisions. The Accounting Review, 88(1), 171-198. https://doi.org/10.2308/accr-50262

Jensen, M. C., \& Meckling, W. H. (1976). Theory of The Firm: Managerial Behavior, Agency Cost and Ownership Structure. Journal of Financial Economics, 3(4), 305-360. https://doi.org/10.1016/0304-405x(76)90026-x

Jiraporn, P., Miller, G. A., Yoon, S. S., \& Kim, Y. S. (2008). Is Earnings Management Opportunistic or Beneficial? An Agency Theory Perspective. International Review of Financial Analysis, 17(3), 622-634. https://doi.org/10.1016/j.irfa.2006.10.005

Jones, T. M. (1991). Ethical Decision Making by Individuals in Organizations: An IssueContingent Model. The Academy of Management Review, 16(2), 366-395. https://doi.org/10.2307/258867

Jouber, H., \& Fakhfakh, H. (2014). The Association between CEO Incentive Rewards and Earnings Management: Do Institutional Feature Matter? EuroMed Journal of Business, 9(1), 18-36. https://doi.org/10.1108/emjb-11-2012-0019

Kahneman, D., \& Tversky, A. (1979). Prospect Theory: An Analysis of Decision Under Risk. Econometrica, 47(2), 263-291. https://doi.org/10.2307/1914185

Kaptein, M. (2011). Toward Effective Codes: Testing the Relationship with Unethical Behavior. Journal of Business Ethics, 99, 233-251. https://doi.org/10.1007/s10551$\underline{010-0652-5}$

Laux, C., \& Laux, V. (2009). Board Committees, CEO Compensation, and Earnings Management. The Accounting Review, 84(3), 869-891. https://doi.org/10.2308/accr.2009.84.3.869

Lucyanda, J., \& Sholihin, M. (2016). Peran Gender dan Kode Etik dalam Penilaian Moral Atas Budgetary Slack. Paperpresented at the Simposium Nasional Akuntansi 19, Lampung. Retrieved from https: $/ / \mathrm{www} \cdot$ google.com/url? sa $=\mathrm{t} \& \mathrm{rct}=j \& \mathrm{q}=\& \mathrm{kesrc}=\mathrm{s} \& \mathrm{source}=\mathrm{web} \& \mathrm{~cd}=1 \& \mathrm{cad}=\mathrm{rja}$ \&uact $=8 \& v e d=2$ ahUKEwiRqsSKuu oAhXMWisKHbvOBVsQFjAAegQIBBAB\&ur l=http $\% 3 \mathrm{~A} \% 2 \mathrm{~F} \% 2 \mathrm{Flib} . \mathrm{ibs} . \mathrm{ac} . \mathrm{id} \% 2 \mathrm{Fmateri} \% 2 \mathrm{FProsiding} \% 2 \mathrm{FSNA} \% 2520 \mathrm{XIX} \% 2520$ (19)\%2520Lampung\%25202016\%2Fmakalah\%2F014.pdf\&usg=AOvVaw1uzzVLdNe Ns5nHUwnbwRmK

Makar, S. D., Alam, P., \& Pearson, M. A. (2000). Earnings Management: When does Juggling the Numbers Become Fraud? Fraud Magazines: A Publication of the Association of Certified Fraud Examiners. Retrieved from https://www.fraudmagazine.com/article.aspx?id $=4294968448$

McCabe, D. L., Trevino, L. K., \& Butterfield, K. D. (1996). The Influence of Collegiate and Corporate Codes of Conduct on Ethics-Related Behavior inthe Workplace. Business Ethics Quarterly, 6(4), 461-476. https://doi.org/10.2307/3857499

McPhail, K., \& Walters, D. (2009). Accounting and Business Ethics. New York: Taylor \& Francis e-Library.

Nahartyo, E., \& Utami, I. (2016). Panduan Praktis Riset Eksperimen. Jakarta Barat: PT Indeks.

Pflugrath, G., Martinov - Bennie, N., \& Chen, L. (2007). The Impact of Codes of Ethics and Experience on Auditor Judgments. Managerial Auditing Journal, 22(6), 566-589.

https://doi.org/10.1108/02686900710759389 
Pohling, R., Bzdok, D., Eigenstetter, M., Stumpf, S., \& Strobel, A. (2016). What is Ethical Competence? The Role of Empathy, Personal Values, and the Five-Factor Model of Personality in Ethical Decision-Making. Journal of Business Ethics, 137(3), 449-474. https://doi.org/10.1007/s10551-015-2569-5

Purnama, I. A., \& Sholihin, M. (2017). Pengaruh Skema Insentif Bonus dan Clawback terhadap Senjangan Anggaran dengan Penalaran Moral sebagai Variabel Pemoderasi. Paper presented at the Simposium Nasional Akuntansi 20 Jember. Retrieved from https: / $/$ www.google.com/url? sa $=t \& r c t=j \& q=\& e s r c=s \& s o u r c e=w e b \& c d=2 \& c a d=r j a$ \&uact=8\&ved=2ahUKEwjziPTwu _oAhX363MBHTCXDWoQFjABegQIAhAB\&u $\mathrm{rl}=\mathrm{http} \% 3 \mathrm{~A} \% 2 \mathrm{~F} \% 2 \mathrm{Frepository} . u n i b . a c . i \mathrm{~d} \% 2 \mathrm{~F} 16854 \% 2 \mathrm{~F} 1 \% 2 \mathrm{FProsiding} \% 2520 \mathrm{SNA}$ $\% 2520 X X \% 25202017 \% 2520$ JEMBER.pdf\&usg=AOvVaw3ExK6JASG neP5 HVE ufu4

Putra, A. M., Pagalung, G., \& Habbe, A. H. (2018). Culture and Corruption-Driven Agency Costs and Earnings Management: Evidence from South East Asian Countries. Intangible Capital, 14(4), 499-517. https://doi.org/10.3926/ic.1289

Pyzoha, J. S. (2015). Why do Restatements Decrease in a Clawback Environment? An Investigation into Financial Reporting Executives' Decision-Making during the Restatement Process. The Accounting Review, 90(6), 2515-2536. https://doi.org/10.2308/accr-51049

Reitenga, A., Buchheit, S., Yin, Q. J., \& Baker, T. (2002). CEO Bonus Pay, Tax Policy, and Earnings Management. The Journal of the American Taxation Association, 24(s-1), 1-23. https://doi.org/10.2308/iata.2002.24.s-1.1

Rezaei, F., \& Roshani, M. (2012). Efficient or Opportunistic Earnings Management with Regard to the Role of Firm Size and Corporate Governance Practices. Interdisciplinary. Journal of Contemporary Research in Business, 3(9), 1312-1322. Retrieved from https: / $/$ www.google.com/url?sa $=t \& r c t=j \& q=\& e s r c=s \& s o u r c e=w e b \& c d=1 \& c a d=$ rja \&uact $=8 \& v e d=2$ ahUKEwifw $34 \mathrm{u}-$ oAhWDbn0KHfAxAuEQFjAAegQIAhAB\&url=https $\% 3 \mathrm{~A} \% 2 \mathrm{~F} \% 2 \mathrm{Fjournal}-$ archieves14.webs.com\%2F13121322.pdf\&usg=AOvVaw1Qgg3AE9DhotJhkwdnZa9n

Rich, A. J., Smith, C. S., \& Mihale, P. H. (1990). Are Corporate Codes of Conduct Effective? Management Accountant, 34-35.

Rodriguez-Dominguez, L., Gallego-Alvarez, I., \& Garcia-Sanchez, I. M. (2009). Corporate Governance and Codes of Ethics. Journal of Business Ethics, 90(2), 187-202. https://doi.org/10.1007/s10551-009-0035-y

Rokeach, M. (1973). The Nature of Human Values. New York: The Free Press.

Sari, R. C., \& Sholihin, M. (2019). Religiosity and Clawback Provision to Curb Earnings Management. Journal of Management, Spirituality \& Religion, 16 (4), 372-390. https://doi.org/10.1080/14766086.2019.1608462

Schipper, K. (1989). Commentary on Earnings Management. Accounting Horizons, 3(4), 91 101.

Schwartz, M. S. (2002). A Code of Ethics for Corporate Code of Ethics. Journal of Business Ethics, 41(1-2), 27-43. https://doi.org/10.1023/a:1021393904930

Scott, W. A. (1965). Personal Values Scale, in Values and Organizations. Chicago: Rand McNally College Publishing Company.

Sekaran, U., \& Bougie, R. (2013). Research Methods for Business. United Kingdom: John Willey \& Sons Ltd. 


\section{Khasanah \& Sholihin}

Code of Ethics, Clawback Incentive Schemes, and Personal Value...

Shafer, W. E., Morris, R. E., \& Ketchand, A. A. (2001). Effects of Personal Values on Auditors' Ethical Decisions. Accounting, Auditing \& Accountability Journal, 14(3), 254277. https://doi.org/10.1108/eum0000000005517

Singh, J. B. (2015). Changes in the Contents of Corporate Codes of Ethics: an Institutional interpretation. European Business Review, 27(4), 369-388. https://doi.org/10.1108/ebr$\underline{11-2014-0078}$

Tyler, T. R. (1990). Why People Obey the Law. New Haven and London: Yale University Press.

Wolk, H. I., Dodd, J. L., \& Rozycki, J. J. (2013). Accounting Theory: Conceptual Issues in a Political and Economic Environment. United States of America: Sage Publication Inc.

Wotruba, T. R., Chonko, L. B., \& Loe, T. W. (2001). The Impact of Ethics Code Familiarity on Manager Behavior. Journal of Business Ethics, 33(1), 59-69.

https://doi.org/10.1023/a:1011925009588 